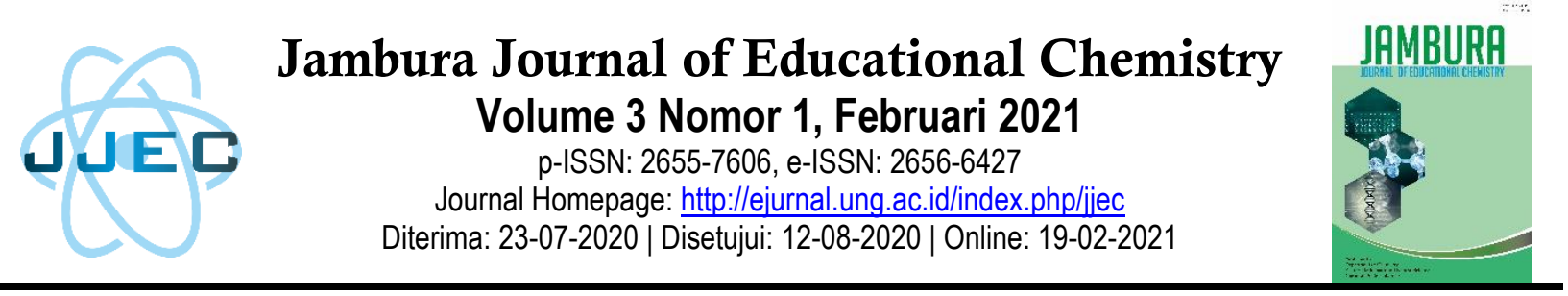

\title{
Pengaruh Pembelajaran Inkuiri Terbimbing Integrasi Peer Instruction Terhadap Penguasaan Konsep dan Kemampuan Berpikir Kritis SMA Terpadu Wira Bhakti pada Materi Reaksi Reduksi Oksidasi (Redoks)
}

\author{
Cicilia Yulianti Saeng1 ${ }^{1}$ Astin Lukum², Deasy N. Botutihe ${ }^{3}$ \\ 1,2 Prodi Pendidikan Kimia, Jurusan Kimia, Fakultas MIPA, Universitas Negeri Gorontalo \\ ${ }^{3}$ Prodi Kimia, Jurusan Kimia, Fakultas MIPA, Universitas Negeri Gorontalo \\ Jl. Prof. Dr. Ing. B. J. Habibie, Moutong, Tilongkabila, Kabupaten Bone Bolango, Gorontalo \\ 96119, Indonesia \\ e-mail: ${ }^{1}$ ciciliasaeng@gmail.com
}

\begin{abstract}
Abstrak
Penelitian ini memiliki tujuan mengetahui pengaruh pembelajaran inkuiri terbimbing integrasi peer instruction terhadap penguasaan konsep dan kemampuan berpikir kritis siswa kelas X SMA Terpadu Wira Bhakti pada materi reaksi reduksi oksidasi (redoks). Penelitian ini merupakan penelitian kuantitatif dengan desain penelitian true experimental design dengan rancangan posttest-only control design. Sampel penelitian adalah siswa kelas X IPA 1 dan X IPA 2 SMA Terpadu Wira Bhakti masing-masing kelas berjumlah 24 siswa. Model pembelajaran yang digunakan pada kelas eksperimen adalah pembelajaran inkuiri terbimbing integrasi peer instruction sedangkan pada kelas kontrol adalah pembelajaran konvensional. Instrument penelitian menggunakan tes objektif 20 butir soal untuk mengukur penguasaan konsep siswa sedangkan tes esai 6 nomor untuk mengukur kemampuan berpikir kritis siswa. Teknik analisis data pada pengujian hipotesis menggunakan uji-t. dengan taraf signifikan $\alpha=0,05$. Berdasarkan hasil perhitungan untuk penguasaan konsep siswa $t_{\text {hitung }}=2,11>t_{\text {tabel }}=1,68$, sedangkan untuk perhitungan kemampuan berpikir kritis siswa diperoleh nilai $\mathrm{t}_{\text {hitung }}=5>\mathrm{t}_{\text {tabel }}=1,68$.
\end{abstract}

Kata kunci: Inkuiri Terbimbing, Peer Instruction, Penguasaan Konsep, Berpikir Kritis, Redoks.

\section{PENDAHULUAN}

Ilmu Pengetahuan Alam (IPA) merupakan ilmu yang berkaitan dengan mencari tahu tentang alam secara sistematis, sehingga IPA bukan hanya penguasaan kumpulan pengetahuan berupa faktafakta, konsep-konsep, atau prinsip-prinsip saja, tetapi juga merupakan suatu proses penemuan. Ilmu Pengetahuan Alam juga merupakan mata pelajaran yang diajarkan pada siswa mulai dari sekolah tingkat dasar sampai perguruan tinggi. Melalui kimia siswa diharapkan mempunyai bekal untuk mampu menguasai kemampuan berpikir logis analitis, sistematis, kritis, kreatif serta kemampuan bekerja sama (Yeritia et al., 2017).

Pembelajaran kimia harus diarahkan untuk mencari tahu dan berbuat sehingga dapat membantu peserta didik untuk memperoleh penguasaan yang lebih mendalam, oleh sebab itu, pembelajaran kimia harus menekankan pada pemberian pengalaman langsung dan berpusat pada siswa. Belajar konsep merupakan hasil utama pendidikan. Dengan demikian, perlu dikembangkan tingkat penguasaan konsep peserta didik. Selain penguasaan konsep, tujuan pembelajaran kimia adalah mengembangkan 
kemampuan berpikir. Kemampuan berpikir merupakan dasar dalam suatu proses pembelajaran (Kurniawati et al., 2014).

Menurut Cakir (Asmawati, 2015) pemahaman konsep yang diperoleh melalui cara mengkonstruksi pemahaman lebih baik jika dibandingkan dengan pemahaman yang diperoleh melalui cara informatif pada kegiatan ceramah. Pengorganisasian suatu proses pembelajaran adalah hal yang sangat penting dalam membangun pemahaman konsep siswa. Proses pembelajaran yang baik bukan hanya memperhatikan penyampaian konsep, tetapi juga memperhatikan proses penyampaian konsep dan proses pemahaman konsep oleh siswa.

Kemampuan berpikir kritis merupakan salah satu keterampilan hidup (life skill) yang penting untuk dimiliki. Kemampuan berpikir kritis adalah kemampuan yang ada pada individu untuk mengambil keputusan autentik dan bertanggung jawab untuk mempengaruhi hidup individu tersebut. Sebab, dengan kemampuan berpikir kritis seseorang akan dapat mandiri, tanggap terhadap permasalahan, dan dapat mengambil keputusan dengan alasan yang logis. Bagi siswa, kemampuan berpikir kritis akan dapat membantunya dalam memahami suatu konsep dengan benar. Siswa yang berpikir kritis akan mampu mengidentifikasi suatu permasalahan, kemudian menganalisis dari berbagai informasi terkait masalah yang sedang dihadapi, dan mengambil kesimpulan yang tepat untuk pemecahan masalahnya tersebut (Lastyono et al., 2012; Nuraeni et al., 2019; Desni et al., 2019).

Salah satu pembelajaran yang memiliki potensi untuk mengembangkan keaktifan siswa dalam pembelajaran adalah Peer instruction. Dalam peer instruction diselingi dengan pertanyaan konsep dan melibatkan keaktifan siswa dalam pembelajaran. Menurut Kurniawati et al., (2014) pembelajaran peer instruction lebih efektif daripada dengan pembelajaran diskusi kelas. Lingkungan belajar yang kaya dengan diskusi sejawat dapat mengembangkan kemampuan berpikir kritis dan penguasaan konsep dalam diri siswa. Berdasarkan hasil penelitian Sari \& Aisyah (2016) model pembelajaran peer instruction dapat dijadikan alternatif model pembelajaran yang sangat potensial untuk dijadikan sarana meningkatkan hasil belajar kimia siswa di tingkat SMA.

Menurut Kurniawati et al., (2014) dan Dewi et al., (2020) inkuiri terbimbing dan peer instruction memiliki banyak manfaat dan karakteristik masingmasing. Penerapan dalam pembelajaran antara inkuiri terbimbing yang diintegrasikan dengan peer instruction akan berbeda dengan pembelajaran yang hanya menerapkan pembelajaran dengan metode inkuiri terbimbing. Dengan demikian, melalui inkuiri terbimbing peserta didik dapat mengkonstruksi pengetahuannya melalui eksperimen, proses berpikir, dan bertanya sedangkan melalui peer instruction peserta didik dapat berpikir lebih maksimal dengan memperkuat pemahaman konsep dan berdiskusi dengan teman sejawatnya. Manfaat dari model pembelajaran inkuiri terbimbing lainnya, yaitu siswa dapat terlibat secara aktif dalam berhipotesis, menganalisis, mengumpulkan beberapa data untuk membuktikan hipotesis, dan mengintegrasikan bukti-bukti yang diperoleh dengan teman dan guru untuk memperoleh simpulan yang benar dan tepat.

Penelitian ini dilakukan dengan tujuan untuk mengetahui apakah terdapat pengaruh pembelajaran inkuiri terbimbing integrasi peer instruction terhadap penguasaan konsep dan kemampuan berpikir kritis siswa pada materi reaksi reduksi oksidasi (redoks).

\section{METODE PENELITIAN}

Penelitian ini dilaksanakan di SMA Terpadu Wira Bhakti, Kabupaten Bone Bolango pada siswa kelas X semester genap tahun pelajaran 2018/2019 dalam kurun waktu \pm 4 bulan, yaitu bulan maret sampai juni tahun 2019. Sampel pada penelitian ini berjumlah 48 siswa yang terbagi menjadi 24 siswa di kelas eskperimen dan 24 siswa di kelas kontrol. Kelas eksperimen yang dibelajarkan dengan pembelajaran inkuiri terbimbing integrasi peer instruction, dan kelas kontrol dibelajarkan dengan pembelajaran konvensional.

Rancangan penelitian yang digunakan adalah true experimental design dengan posttestonly control design. 


\section{Teknik Pengumpulan Data}

Teknik pengumpulan data dari hasil kemampuan kognitif siswa pada penelitian ini diperoleh melalui instrument tes. Tes yang digunakan adalah tes penguasaan konsep berupa tes objektif sebanyak 20 butir soal dan tes kemampuan berpikir kritis siswa berupa tes esai sebanyak 6 butir soal. Tes ini digunakan untuk mengetahui apakah terdapat peningkatan penguasaan konsep dan kemampuan berpikir kritis siswa setelah diberikan perlakuan pembelajaran inkuiri terbimbing integrasi peer instruction. Pemberian tes ini dilakukan setelah proses pembelajaran selesai (posttest). Aspek afektif dan psikomotor siswa dievaluasi selama kegiatan pembelajaran berlangsung dengan menggunakan lembar observasi.

\section{Teknik Analisis Data}

Teknik analisis data yang digunakan dalam penelitian ini terdiri dari dua bagian yaitu analisis data deskriptif dan analisis data inferensial. Menurut Sugiyono (2011) analisis data deskriptif ini digunakan untuk mendeskripsikan atau menggambarkan data yang telah dikumpulkan dimana analisis deskriptif yang digunakan pada penelitian ini adalah mean, median dan modus. Sedangkan analisis data inferensial digunakan untuk menguji hipotesis penelitian.

Pengujian hipotesis dalam penelitian ini menggunakan uji t. Menurut Nana (2005) uji t yang digunakan adalah uji $t$ satu pihak dengan rumus sebagai berikut:

$$
t=\frac{\overline{\mathrm{x}}_{1}-\overline{\mathrm{x}}_{2}}{\sqrt[\mathrm{s}]{\frac{1}{\mathrm{n}_{1}}+\frac{1}{\mathrm{n}_{2}}}}
$$

Dengan :

$$
S^{2}=\frac{\left(\mathrm{n}_{1}-1\right) \mathrm{S}_{1}^{2}+\left(\mathrm{n}_{2}-2\right) \mathrm{S}_{2}^{2}}{\mathrm{n}_{1}+\mathrm{n}_{2}-2}
$$

Keterangan :

$\mathrm{t}=$ Nilai hitung untuk uji $\mathrm{t}$

$\overline{\mathrm{x}}_{1}=$ Nilai rata-rata kelas eksperimen

$\overline{\mathrm{x}}_{2}=$ Nilai rata-rata kelas kontrol

$\mathrm{n}_{1}=$ Jumlah anggota sampel kelas eksperimen

$\mathrm{n}_{2}=$ Jumlah anggota sampel kelas kontrol

$\mathrm{S}_{1}^{2}=$ Standar deviasi kelas eksperimen

$\mathrm{S}_{2}^{2}=$ Standar deviasi kelas kontrol

$\mathrm{S}^{2}=$ Varians sampel

Kriteria Pengujian:
Terima $\mathrm{H}_{0}$ jika : $\mathrm{t}_{\text {tabel }}>\mathrm{t}_{\text {hitung }}$ dengan $\mathrm{dk}=\left(\mathrm{n}_{1}\right.$ $+\mathrm{n}_{2}-2$ ), pada taraf signifikasi $\alpha=0,05$, dan tolak $\mathrm{H}_{0}$ jika t mempunyai harga lain.

\section{HASIL DAN PEMBAHASAN}

Data pada penelitian ini terdiri dari dua kelompok data yaitu data penguasaan konsep dan kelompok data kemampuan berpikir kritis siswa pada materi reaksi reduksi oksidasi (redoks). Data diperoleh dari hasil yang diuji pada siswa dengan menggunakan instrumen tes objektif/ pilihan ganda sebanyak 20 butir soal yang digunakan untuk menguji penguasaan konsep siswa dan instrument tes esai sebanyak 6 butir soal untuk menguji kemampuan berpikir kritis siswa, yang kemudian data tersebut diolah secara kuantitatif dengan menggunakan uji statistik. Data yang dipaparkan berupa rata-rata (mean), median, modus, standar deviasi, varians, dan digambarkan dalam bentuk tabel distribusi dan histogram.

Kemudian pada penelitian ini juga dilakukan observasi aspek afektif dan psikomotor siswa dengan indikator pada tiap aspek berbedabeda. Observasi tersebut dilakukan selama proses pembelajaran berlangsung.

\section{Data Pembelajaran Aspek Afektif Siswa}

Kemampuan siswa pada ranah afektif pada dasarnya mencakup watak, perilaku seperti perasaan, minat, sikap, emosi, atau nilai yang dapat menentukkan keberhasilan belajarnya. Data aspek afektif belajar siswa pada penelitian ini diperoleh berdasarkan pengamatan langsung kepada siswa, dimana aspek yang dinilai yaitu penerimaan (receiving), tanggapan (responding), penghargaan (valuing), pengorganisasian (organization), dan karakterisasi (characterization). Hasil observasi ranah afektif siswa untuk kelas eksperimen dan kelas kontrol disajikan pada Gambar 1, dimana pada pertemuan pertama nilai rata-rata siswa kelas eskperimen yaitu 84,72 lebih tinggi dibandingkan kelas kontrol dengan nilai rata-rata 79,4. Pada pertemuan kedua nilai rata-rata kelas eksperimen 87,5 sedangkan pada kelas kontrol nilai rata-rata yang diperoleh adalah 86,94 . 


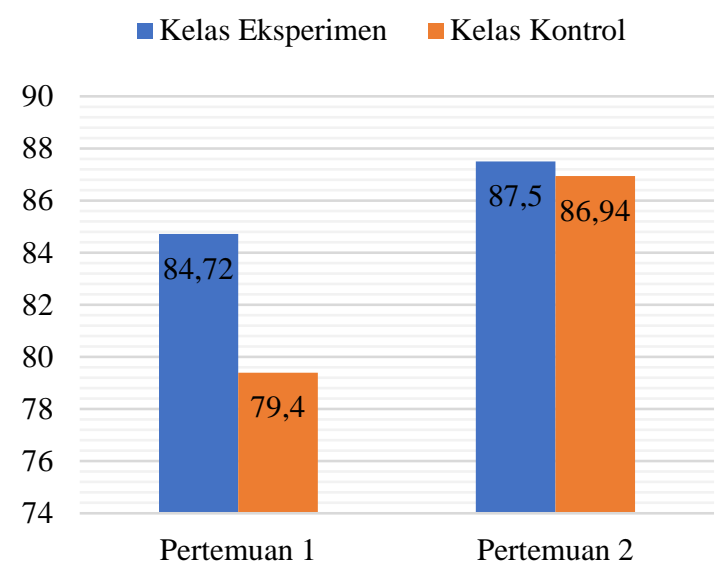

Gambar 1. Nilai Rata-Rata Aspek Afektif Siswa Pada Kelas Eksperimen Dan Kelas Kontrol

\section{Data Pembelajaran Aspek Psikomotor Siswa}

Data aspek psikomotor pada penelitian ini diperoleh dari diskusi siswa dalam proses pembelajaran. Aspek yang dinilai yaitu imitasi, manipulasi, dan artikulasi. Nilai rata-rata aspek psikomotor siswa kelas kontrol dan ekperimen disajikan pada Gambar 2. Pada pertemuan pertama nilai aspek psikomotor siswa kelas eksperimen dan kelas kontrol berturut-turut adalah 79,86 dan 73,61. Pada pertemua kedua nilai rata-rata siswa kelas eksperimen 86,81 sedangkan kelas kontrol 85,42.

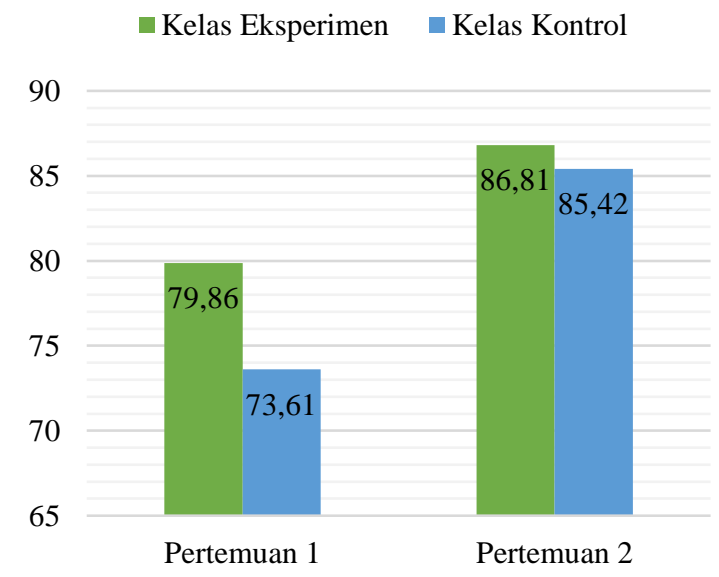

Gambar 2. Nilai Rata-rata Aspek Psikomotor Siswa Pada Kelas Eksperimen Dan Kelas Kontrol

\section{Data Pembelajaran Aspek Kognitif Siswa \\ a. Pengaruh Pembelajaran Inkuiri Terbimbing Integrasi Peer Instruction Terhadap Penguasaan Konsep Siswa}

Hasil posttest penguasaan konsep siswa kelas eksperimen dan kontrol diperoleh nilai ratakelas eskperimen 80,63 dan kelas kontrol 74,17 dapat dilihat pada Gambar 3. Jumlah siswa yang tuntas pada kelas eksperimen adalah 20 orang siswa dan yang tidak tuntas adalah 4 orang siswa sedangkan pada kelas kontrol yaitu 14 orang siswa dan yang tidak tuntas adalah 10 orang dengan nilai tertinggi kelas eksperimen adalah 100 sedangkan nilai terendah adalah 55 dan pada kelas kontrol diperoleh nilai tertinggi siswa adalah 95 sedangkan nilai terendah adalah 50 .

Berdasarkan data penguasaan konsep siswa tersebut dilakukan uji normalitas data dan uji homogenitas data dengan menggunakan taraf signifikan 0,05 , untuk uji normalitas menggunakan uji liliefors sementara untuk uji homogenitas menggunakan uji F. Hasil uji normalitas data diperoleh nilai posttest kelas eksperimen sebesar $\mathrm{L}_{\text {hitung }}=0,13<\mathrm{L}_{\text {tabel }}=0,18$ dan kelas kontrol memperoleh nilai posttest sebesar $\mathrm{L}_{\text {hitung }}=0,11<$ $\mathrm{L}_{\text {tabel }}=0,18$ artinya bahwa pada kedua kelas tersebut berdistribusi normal. Hasil uji homogenitas diperoleh data penguasaan konsep siswa adalah $F_{\text {hitung }}=0,13<\mathrm{F}_{\text {tabel }}=2,01$ artinya berada pada daerah penerimaan $\mathrm{H}_{0}$, maka $\mathrm{H}_{0}$ diterima sehingga dapat disimpulkan bahwa kedua kelas homogen dan dapat dilakukan uji t, karena syarat dilakukannya uji $\mathrm{t}$ adalah data pada kedua kelas harus homogen.

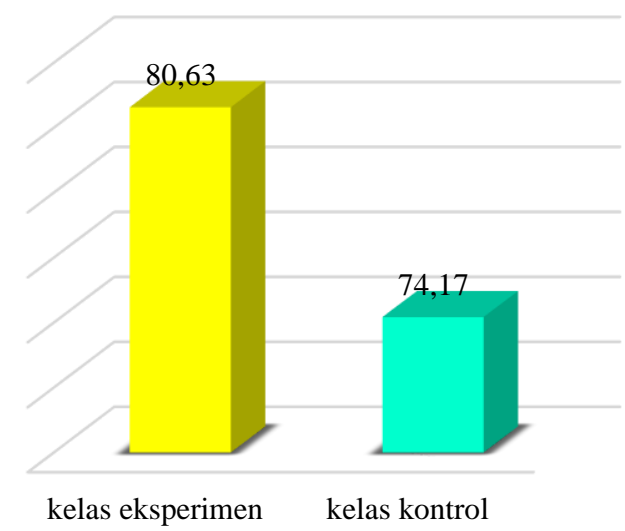

Gambar 3. Nilai Rata-rata Posttest Penguasaan Konsep Siswa 
Pengujian hipotesis dilakukan dengan menggunakan uji $\mathrm{t}$ dua pihak yang mempunyai taraf signifikan $\alpha=0,05$ diperoleh nilai $t_{\text {hitung }}=2,11>t_{\text {tabel }}$ $=1,68$, maka dapat disimpulkan bahwa $\mathrm{H}_{0}$ ditolak dan $\mathrm{H}_{1}$ diterima. Hal ini berarti penguasaan konsep siswa kelas eksperimen mempunyai nilai lebih tinggi daripada kelas kontrol.

Penguasaan konsep redoks oleh siswa yang mengikuti model pembelajaran inkuiri terbimbing integrasi peer instruction yang lebih tinggi dibanding penguasaan konsep siswa yang mengikuti model pembelajaran konvensional selaras dengan penelitian yang dilakukan oleh Kurniawati et al., (2014) yang mengemukakan bahwa pembelajaran inkuiri terbimbing intergrasi peer instruction memudahkan siswa dalam menemukan dan mengembangkan konsep pada saat praktikum pada tahap menguji hipotesis secara peer dan berdiskusi secara peer di setiap tahap sehingga dapat lebih mudah menguasai konsep dalam pembelajaran. Selain itu, diskusi secara peer juga membuat siswa lebih mudah mengingat informasi.

\section{b. Pengaruh Pembelajaran Inkuiri Terbimbing Integrasi Peer Instruction Terhadap Kemampuan Berpikir Kritis Siswa}

Data diperoleh dari hasil posttest yang diberikan kepada siswa dengan waktu yang sama ketika diberikan soal penguasaan konsep siswa. Butir soal untuk kemampuan berpikir kritis adalah soal esai yang terdiri dari 6 butir soal, dengan rentang skor pada masing-masing butir soal yaitu 0 -3 dengan tiap soal mewakili 1 indikator berpikir kritis yang terdiri dari memberikan penjelasan sederhana, membangun keterampilan dasar, menyimpulkan, memberi penjelasan lanjut, serta mengatur strategi dan teknik. Hasil yang diperoleh adalah nilai rata-rata kelas eksperimen 84,92 dan rata-rata kelas kontrol 77,71 (Gambar 4). Skor terendah kelas ekperimen adalah 67 dan tertinggi adalah 100, untuk kelas kontrol skor terendah 61 dan skor tertinggi 100. Jumlah siswa yang tuntas pada kelas eksperimen adalah 20 orang dengan persentase $83,3 \%$ termasuk dalam kategori memiliki kemampuan berpikir kritis tinggi. Pada kelas kontrol jumlah siswa yang tuntas adalah 15 orang siswa dengan persentase kemampuan berpikir kritis pada kelas kontrol adalah 62,5\% termasuk dalam kategori memiliki kemampuan berpikir kritis yang rendah.

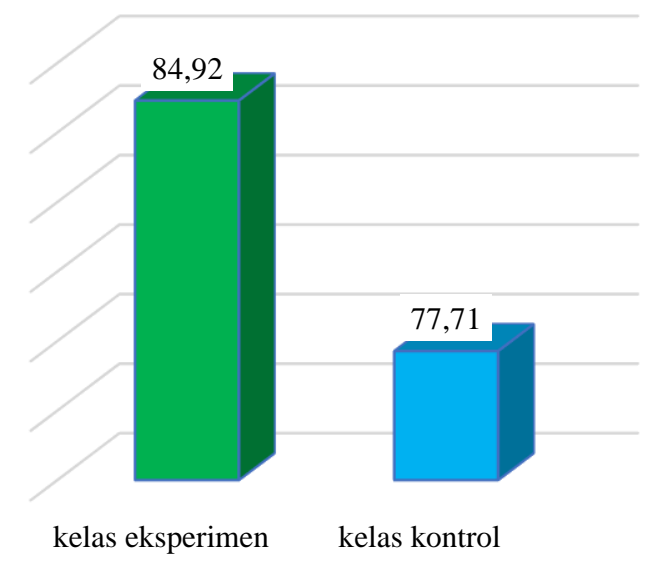

Gambar 4. Nilai Rata-rata Posttest Kemampuan Berpikir Kritis Siswa

Selanjutnya dilakukan pengujian normalitas data dengan menggunakan rumus uji liliefors dengan taraf signifikan $\alpha=0,05$. Hasil perhitungan menunjukkan bahwa untuk kelas eksperimen diperoleh $\mathrm{L}_{\text {hitung }} 0,15<\mathrm{L}_{\text {tabel }} 0,18$, kelas kontrol $\mathrm{L}_{\text {hitung }} 0,14<\mathrm{L}_{\text {tabel }} 0,18$. Artinya kedua data tersebut berdistribusi normal.

Langkah selanjutnya adalah dilakukan pengujian homogenitas data dengan menggunakan rumus uji $\mathrm{F}$ dengan taraf signifikan $\alpha=0,05$. Pengujian homogenitas dilakukan dengan tujuan untuk menguji kesamaan rata-rata dua varians. Hasil perhitungan diperoleh $\mathrm{F}_{\text {hitung }}<\mathrm{F}_{\text {tabel }}$ atau 1,12 $<2,01$ berada pada daerah penerimaan $\mathrm{H}_{0}$, Maka $\mathrm{H}_{0}$ diterima sehingga disimpulkan bahwa kedua kelas Homogen.

Pengujian hipotesis dalam penelitian ini menggunakan uji t dua pihak yang mempunyai taraf signifikan $\alpha=0,05$, maka dperoleh $t_{\text {hitung }}=5>t_{\text {tabel }}$ = 1,68, maka berarti $\mathrm{H}_{0}$ ditolak dan $\mathrm{H}_{1}$ diterima. Berdasarkan pengujian hipotesis tersebut disimpulkan bahwa terdapat perbedaan kemampuan berpikir kritis siswa yang menggunakan pembelajaran inkuiri terbimbing integrasi peer instruction dengan pembelajaran konvensional. Dengan demikian rata-rata kemampuan berpikir kritis siswa yang menggunakan pembelajaran inkuiri terbimbing integrasi peer instruction lebih tinggi dibandingkan dengan pembelajaran 
konvensional. Kurniawati et al., (2014) mengemukakan bahwa siswa yang terlibat langsung dalam eksperimen dan aktif dalam pembelajaran juga lebih mudah untuk mengasah kemampuan berpikir kritisnya. Sehingga ketika diberikan permasalahan dapat mengundang siswa dapat mengajukan pertanyaan dan membuat hipotesis melalui proses berpikir. Siswa yang diberi perlakuan dengan diskusi mempunyai tingkat berpikir kritis yang lebih baik daripada siswa yang belajar secara individual. Oleh sebab itu, nilai kemampuan berpikir kritis siswa yang belajar dengan pembelajaran inkuiri terbimbing integrasi peer instruction lebih tinggi daripada siswa yang belajar dengan pembelajaran konvensional.

\section{KESIMPULAN}

Berdasarkan hasil penelitian yang telah dilakukan maka dapat disimpulkan bahwa: (a) Terdapat pengaruh pembelajaran inkuiri terbimbing integrasi peer instruction terhadap penguasaan konsep siswa kelas X SMA Terpadu Wira Bhakti pada materi reaksi reduksi oksidasi (redoks), hal ini dapat dilihat berdasarkan hasil uji $\mathrm{t}$ dengan menggunakan taraf signifikan $\alpha=0,05 t_{\text {hitung }}=2,11$ $>\mathrm{t}_{\text {tabel }}=1,68$; (b) Hasil penelitian yang dilakukan juga menunjukkan bahwa terdapat pengaruh pembelajaran inkuiri terbimbing integrasi peer instruction terhadap kemampuan berpikir kritis siswa kelas X SMA Terpadu Wira Bhakti. Dimana hasil pengujian hipotesis menunjukkan bahwa Pengujian hipotesis dalam penelitian ini menggunakan uji t dua pihak yang mempunyai taraf signifikan $\alpha=0,05$, maka dperoleh $\mathrm{t}_{\text {hitung }}=5>\mathrm{t}_{\text {tabel }}$ $=1,68$.

Dari kedua data tersebut dapat disimpulkan bahwa pembelajaran inkuiri terbimbing integrasi peer instruction berpengaruh positif terhadap penguasaan konsep siswa dan kemampuan berpikir kritis siswa SMA Terpadu Wira Bhakti.

\section{DAFTAR PUSTAKA}

Asmawati, E. Y. (2015). Lembar kerja siswa (LKS) menggunakan model guided inquiry untuk meningkatkan keterampilan berpikir kritis dan penguasaan konsep siswa. Jurnal Pendidikan Fisika, 3(1).
Desni, N. W., Sihaloho, M., \& Pikoli, M. (2019). Studi Komparasi Kemampuan Berpikir Kritis Siswa Menggunakan Model Pembelajaran Problem Based Learning dan Discovery Learning Pada Materi Larutan Penyangga di Kelas XI SMA Negeri 1 Telaga. Jambura Journal of Educational Chemistry, 1(2), 6368.

Dewi, C., Utami, L., \& Octarya, Z. (2020). Pengaruh Model Pembelajaran Inkuiri Terbimbing Integrasi Peer Instruction terhadap Kemampuan Berpikir Kritis Siswa SMA pada Materi Laju Reaksi. Journal of Natural Science and Integration, 3(2), 196. https://doi.org/10.24014/jnsi.v3i2.9100

Kurniawati, I. D., Wartono, \& Diantoro, M. (2014). Pengaruh pembelajaran inkuiri terbimbing integrasi peer instruction terhadap penguasaan konsep dan kemampuan berpikir kritis siswa. Jurnal Pendidikan Fisika Indonesia, 10(1).

Lastyono, J., Slamet, R., \& Marheni, M. (2012). Upaya Meningkatkan Kemampuan Berpikir Kritis Siswa Melalui Pendekatan Savi pada Materi Redoks di Kelas X SMA Negeri 52 Jakarta. JRPK: Jurnal Riset Pendidikan Kimia, 2(1), 91-98.

Nana, S. (2005). Penilaian Hasil Proses Belajar Mengajar. Bandung: Rosda Karya.

Nuraeni, S., Feronika, T., \& Yunita, L. (2019). Implementasi Self-Efficacy dan Keterampilan Berpikir Kritis Siswa Pada Pembelajaran Kimia di Abad 21. Jambura Journal of Educational Chemistry, 1(2), 4956.

Sari, R., \& Aisyah, S. (2016). Penerapan Peer Instruction With Structured Inquiry ( Pisi ) Untuk Meningkatkan Hasil Belajar Kimia Siswa. 1(2), 176-188.

Sugiyono. (2011). Metodologi penelitian kuantitatif kualitatif dan $R \& D$. Alfabeta.

Yeritia, S., Wahyudi, W., \& Rahayu, S. (2017). Pengaruh model pembelajaran inkuiri terbimbing terhadap penguasaan konsep dan kemampuan berpikir kritis fisika peserta didik kelas X SMAN 1 Kuripan tahun ajaran 2017/2018. Jurnal Pendidikan Fisika Dan Teknologi, 3(2), 181-187. 